\section{Akad Tijarah Dalam Praktek Di Lembaga Keuangan Mikro Syariah - BM T}

\author{
N andang Ihwanudin*, H andri, Deden G andana \\ Madjakusumah, $M$ M unir A srori \\ Program Studi Magister Manajemen Ekonomi Syariah \\ Universitas Islam Bandung
}

\begin{abstract}
A bstract
Purpose- A kad tijarah as a form of trade agreement has several type, in which needs to be adjusted to each necessity. It is important for related parties to understand what and how akad ijarah works. This article analyse how far the contribution of Islamic microfinance institution (LKM S) now days, considering there are nash (AI-Q ur' an and A I-H adits) and also fatwa the national sharia council (DSN) MUI. Methods- Case studies and literature reviews are used to evaluate sharia business practices in BM T. Findings- Sharia microfinance institutions, in this case BM T TUM ANG, have carried out sharia principles in practice, especially for tijarah agreements with documents in the form of SOM and SOP as well as financing contracts (agreements), both in the principle of sale and profit sharing. Implications/Limitations- This study is limited to one branch of the BM T so it cannot describe the overall practice carried out in other regions.
\end{abstract}

\begin{abstract}
A bstrak
Tujuan- Artikel ini menganalisis sejauh mana kontribusi lembaga keuangan mikro syariah (LKMS) saat ini, mengingat ada nash (AlQur'an dan Al-Hadits) dan juga fatwa dewan syariah nasional (DSN) MUI. Metode- Studi kasus dan tinjauan literatur digunakan untuk mengevaluasi praktik bisnis syariah di BMT. Temuanlembaga keuangan mikro syariah, dalam hal ini BMT TUMANG, telah melaksanakan prinsip syariah dalam praktiknya, khususnya untuk perjanjian tijarah dengan dokumen dalam bentuk SOM dan SOP serta kontrak pembiayaan (perjanjian), baik dalam prinsip penjualan maupun laba berbagi. Implikasi / KeterbatasanPenelitian ini terbatas pada satu cabang BMT sehingga tidak dapat menggambarkan keseluruhan praktik yang dilakukan di daerah lain.
\end{abstract}

Pedoman Sitasi: Ihwanudin, N., Handri, Madjakusumah, D.G., \& Asrori, M.M (2020). Akad Tijarah Dalam Praktek Di Lembaga Keuangan Mikro Syariah - BMT. SERAMBI: Jurnal Ekonomi M anajemen dan Bisnis Islam, 2(1), 15 - 28.

D OI: https:/ / doi.org/ 10.36407/ serambi.v2i1.142

\section{SERAM BI}

Received 12 Jan 2020

Revised 14 Apr 2020

Accepted 25 A pr 2020

Online first 30 A pr 2020

\section{Paper type}

Literature review

Email :

nandangihwanudin_mes @unisba.ac.id

Keywords: Tijarah, akad, LKM S-BM T

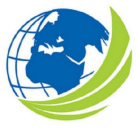

SERAMBI : Jurnal Ekonomi dan Bisnis Islam, Vol 2, No.1, 2020, pp. 15-28

el SSN 2685-9904 


\section{Pendahuluan}

Berpegang pada Wahyu Ilahi dan Sunnah Rasul yang mengajarkan untuk berusaha mendapatkan kehidupan yang baik di dunia dan sekaligus memperoleh kehidupan yang baik di akherat merupakan kewajiban bagi pemeluk Islam. Kehidupan yang baik inilah yang dapat menjamin dicapainya kesejahteraan lahir dan batin melalui ibadah dan muamalah. Dalam masalah muamalah selalu berkaitan dengan berbagai aktivitas kehidupan sehari-hari, terutama dalam masalah ekonomi yang tentunya akan sering kali ditemui sebuah perjanjian atau akad, karena hidup ini dipenuhi oleh gejala ekonomi (Athoillah dan Anees, 2013).

Pada dasarnya akad itu sama dengan transaksi atau serah terima. Semua perikatan yang dilakukan oleh dua pihak atau lebih, tidak boleh menyimpang dan harus sejalan dengan syariat Islam. Tidak boleh ada kesepakatan untuk menipu orang lain, transaksi barang-barang yang di haramkan, dan kesepakatan membuat kerusakan (fasad). Dalam Islam mengenal dua macam akad yaitu : Akad tijarah dan akad tabarru'. Akad tabarru' bertujuan untuk tolong menolong dalam rangka berbuat kebaikan, dan akad tijarah bertujuan untuk mencari keuntungan karena itu bersifat komersial. Bagaimana akad tijarah itu dilakukan, Islam telah mengatur dengan jelas agar tidak mengandung unsur riba, sebagaimana Allah subhana wa ta'ala berfirman :

"Hai orang-orang yang beriman, janganlah kamu saling memakan harta sesamamu dengan jalan yang batil, kecuali dengan jalan perniagaan yang berlaku dengan suka sama-suka di antara kamu........." (Al-Qur'an, 4:29)

Demikian juga Nabi shallallahu 'alaihi wa sallam bersabda : "Tiga hal yang di dalamnya terdapat keberkahan : jual beli secara tangguh, muqaradhah (mudharabah), dan mencampur gandum dengan tepung untuk keperluan rumah, bukan untuk dijual" (HR Ibnu Majah dari Suhaib AI-Rumi Ra)

Lembaga keuangan mikro syariah (LKMS) yang menjalankan fungsi intermediary dengan prinsip syariah dan berskala mikro akan bersinggungan dengan akad tijarah dalam menghimpun dan menyalurkan dana dari masyarakat (umat), dengan demikian harus diketahui apa yang dimaksud dengan akad tijarah, bagaimana akad tijarah dilakukan, dan mengapa lembaga keuangan mikro syariah menggunakan akad tijarah, khususnya para pihak yang ber-akad agar tidak terjadi unsur kerusakan dalam perniagaan tersebut. Untuk memperoleh jawaban atas halhal tersebut penulis mengambil salah satu LKMS dalam praktek datau implementasi sebagaimana yang dimaksud yaitu BMT (baitul mal wat-tamwil).

Studi mengenai akad tijarah sudah pernah dilakukan, antara lain studi UIfa (2018) yang dilakukan pada PT. Sun Life Financial Syariah Cabang Banda Aceh memberikan kesimpulan bahwa produk Brilliance Hasanah Sejahtera (BHS) dapat dikategorikan sebagai produk asuransi jiwa dan investasi melalui pembayaran berkala untuk membantu keluarga dan masyarakat dalam mencapai kebutuhan keuangan dimasa depan seperti dana hari tua yang dikelola berdasarkan prinsip syariah. Studi lain oleh Nugraheni (2016) pada PT. Prudential Life Assurance, dan PT. Takaful Keluarga memberikan beberapa catatan bahwa akad tijarah yang dipergunakan adalah akad wakalah bil ujrah yang berisi pemberian kuasa kepada perusahaan sebagai wakil pemegang polis untuk mengelola Dana Tabarru' dan atau dana investasi, dengan imbalan berupa ujrah. Perusahaan selaku penerima kuasa pengelolaan dana investasi tidak bertanggung jawab terhadap kerugian investasi dikarenakan pemegang polis telah memilih jenis investasi dan mengetahui risiko dari jenis investasi tersebut.

Penelitian ini bertujuan untuk memperluas studi sebelumnya dengan fokus pada penerapan akad tijarah dalam praktek di lembaga keuangan mikro syariah. Selain dapat 
digunakan sebagai bahan evaluasi internal, studi ini juga dapat dijadikan informasi kepada pembaca mengenai kepatuhan perbankan syariah dalam menerapkan fatwa dewan syariah nasional (DSN) MUI dalam kaitannya dengan A kad tijarah.

\section{Kajian Pustaka}

Pembahasan terkait dengan akad tijarah ini dimulai dengan mempelajari beberapa karya tulis, buku-buku, jurnal, tesis, skripsi, dan tulisan lain tentang hal yang sama. Sudah banyak mereka yang dalam karya tulisnya mengambil topik atau pembahasan tentang tijarah atau akad tijarah, namun masih sedikit atau bahkan belum ada yang mengkaitkan dengan praktek akad (pembiayaan) yang ada di lembaga keuangan mikro syariah, dan lebih lagi LKMS itu baitul mal wat-tamwil (BMT). Dari lima karya tulis yang dibaca dan dipahami penulis masing-masing membahas terkait dengan tijarah, yaitu :

Pertama, Tazkiah Ashfia dkk, Fakultas Hukum Universitas Brawijaya membahas akad tijarah dengan judul analisis pengaturan akad tabarru' dan akad tijarah pada asuransi syariah menurut fatwa DSN nomor 21/ DSN-MUI/ X/ 2001 tentang pedoman umum asuransi syariah (2015), yang menekankan tentang sinkronisasi dua ketentuan (ke-empat dan ke-enam) dalam fatwa tersebut dan berdasarkan penelitiannya masing-masing mempunyai dasar hukumnya dengan menambahkan agar tidak terjadi ke-ambiguan dalam memahami dua ketentuan tersebut seharusnya dimasukkan frase terkait subyek yang terlibat dalam dua ketentuan tersebut agar lebih jelas, dan ketentuan tentang akad tabarru' tidak dapat diubah menjadi akad tijarah adalah yang berlaku bagi peserta asuransi.

Kedua, Destri Budi Nugraheni, Fakultas Hukum Universitas Gadjah Mada Yogyakarta, membahas akad tijarah dengan judul analisis yuridis akad tabarru' dan akad tijarah dalam produk unit link syariah (2016), yang menekankan tentang akad tijarah yang dipergunakan oleh PT AXA Finance Indonesia, PT Prudential Life Assurance, dan PT Takaful Keluarga adalah akad wakalah bil ujroh yang berisi pemberian kuasa kepada perusahaan sebagai wakil pemegang polis untuk mengelola dana tabarru' dan atau dana investasi dengan imbalan ujroh.

Ketiga, Andi Zulfikar Darussalam dkk, Fakultas Ekonomi dan Bisnis Universitas Internasional Semen Indonesia, membahas akad tijarah dengan judul konsep perdagangan dalam tafsir al-mishbah (paradigma filsafat ekonomi qur'ani ulama indonesia) (2017), yang menekankan tentang konsep tijarah memiliki subyek obyek arti dan konteknya berbeda antara ayat satu dengan ayat lainnya tapi punya korelasi yang sama yakni bisnis atau trading dimana ada profit atau loss.

Keempat, Cut Afuziah, Institut Agama Islam Negeri Langsa, membahas akad tijarah dengan judul at-tijarah (perdagangan) dalam al-qur'an, yang menekankan tentang persamaan dan perbedaan interpretasi antara Al-Qurtubi dengan Quraish Shihab dalam memaknai ayat tijarah (perdagangan) dalam AI-Qur'an. Persamaannya bahwa ayat-ayat diungkapkan pada isuisu yang dibahas pada tijarah (perdagangan). Perbedaannya cara memaknai ayat tijarah (perdagangan) AI-Qurtubi mengatakan ayat-ayat tersebut menggambarkan tijarah (perdagangan) ke depan dengan aspek hukum (gaya penafsiran fiqih). Sementara Quraish Shihab mengatakan bahwa perdagangan harus dibentuk dengan kesediaan antara penjual dan pembeli.

Kelima, Mashuri, Universitas I slam Negeri Alaudin M akassar, yang membahas akad tijarah dengan judul konsep al-tijarah dalam al-qur'an, yang menekankan bahwa al-tijarah mempunyai dua pengertian. Pertama, perdagangan yang bermakna materi dalam hal aktivitas jual-beli (dagang). Kedua, perdagangan yang bermakna non-materi (amal shaleh), yaitu meningkatkan 
kesejahteraan hidup, menghargai waktu, hemat cermat dalam membelanjakan harta sebagai altijarah dal am membangun ekonomi.

Berdasarkan penjelasan di atas dapat penulis pahami bahwa karya tulis dari penulispenulis tersebut di atas tidak memfokuskan perhatiannya pada praktek atau implementasi akad tijarah dalam lembaga keuangan mikro syariah bahkan baitul mal wat-tamwil. Oleh karenanya, dalam hal ini penulis berpendapat bahwa "akad tijarah dalam praktek di lembaga keuangan mikro syariah - BMT" ini sebagai subyek yang baru atau belum ada yang menyajikannya, paling tidak dari lima karya tulis sebagaimana penulis sampaikan tersebut di atas.

\section{Metode Penelitian}

Jenis penelitian yang digunakan adalah evaluasi, yaitu penelitian yang ditujukan untuk membandingkan satu kejadian, kegiatan, atau produk dengan standar dan program yang telah diterapkan (Hendryadi et al. 2019), dalam hal ini adalah A kad tijarah yang diterapkan pada salah satu bank syariah. Pendekatan studi adalah kualitatif dengan pendekatan studi kasus. Pengelolahan data menggunakan teknik-teknik pengutipan langsung dan tidak langsung melalui berbagai sumber referensi. Sumber referensi ini kemudian dijadikan sebagai stadnar dan dibandingkan dengan praktik di lapangan.

\section{Hasil dan Diskusi}

Tijarah dalam A I-Q ur'an dan A I-H adits.

Terdapat beberapa ayat dalam AI-Qur'an yang menurut penafsiran (Quraish Shihab, 2011) menjelaskan tentang konteks muamalah (Adam, 2017), yaitu :

Pertama, Al-Qur’an Surat Al-Baqarah (2) Ayat 282, yang artinya : “........., kecuali jika mu'amalah itu perdagangan tunai yang kamu jalankan di antara kamu, M aka tidak ada dosa bagi kamu, (jika) kamu tidak menulisnya. dan persaksikanlah apabila kamu berjual beli; dan janganlah penulis dan saksi saling sulit menyulitkan. jika kamu lakukan (yang demikian), M aka Sesungguhnya hal itu adalah suatu kefasikan pada dirimu. dan bertakwalah kepada Allah; Allah mengajarmu; dan Allah Maha mengetahui segala sesuatu." Tijarah dalam ayat ini diartikan sebagai "perdagangan". Jika perdagangan yang dilakukan secara tunai, maka tidak mengapa jika tidak menuliskan transaksinya, hal ini berbeda dengan penggalan awal ayat bercerita tentang perdagangan dalam bentuk utang-piutang yang menganjurkan untuk menuliskan disertai adanya saksi dari transaksi tersebut.

Kedua, Al-Qur'an Surat An-Nisa' (4) Ayat 29, yang artinya : “ $\mathrm{H}$ ai orang-orang yang beriman, janganlah kamu saling memakan harta sesamamu dengan jalan yang batil, kecuali dengan jalan perniagaan yang berlaku dengan suka sama-suka di antara kamu. dan janganlah kamu membunuh dirimu; Sesungguhnya Allah adalah M aha Penyayang kepadamu". Tijarah dalam ayat ini diartikan sebagai "perniagaan". Perniagaan yang diridhoi Allah adalah dengan syarat perniagaan yang berdasarkan kerelaan/ saling ridho (yang tidak melanggar ketentuan agama) atau ketiadaan paksaan (Quraish Shihab, 2011) diantara pihak yang bertransaksi, yaitu orang yang memberi utang (kreditur) ataupun yang berutang (debitur), dimana penggalan ayat sebelumnya bercerita akan larangan memperoleh harta secara batil (tidak sesuai dengan tuntunan syari'at), dan pada penggalan kalimat terakhir untuk menghindari bunuh diri dari segala aktivitas khususnya perniagaan yang mereka lal ui dalam kehidupan.

Ketiga, AI-Qur'an Surat At-Taubah (9) Ayat 24, yang artinya : "Katakanlah: "Jika bapa-bapa, anak-anak, saudara-saudara, isteri-isteri, kaum keluargamu, harta kekayaan yang kamu usahakan, perniagaan yang kamu khawatiri kerugiannya, dan tempat tinggal yang kamu sukai, adalah lebih kamu 
cintai dari Allah dan Rasul-Nya dan dari berjihad di jalan-Nya, Maka tunggulah sampai Allah mendatangkan Keputusan-N ya, dan Allah tidak memberi petunjuk kepada orang-orang yang fasik". Tijarah dalam ayat ini diartikan sebagai "perniagaan". Memang kecintaan kepada sesuatu diukur ketika seseorang dihadapkan kepada dua hal atau lebih yang harus dipilih salah satunya. Dalam konteks ini, jika kenikmatan duniawi disandingkan dengan nilai-nilai Ilahi, Ialu harus dipilih salah satunya, cinta yang lebih besar akan terlihat saat menjatuhkan pilihan. Perlu juga dicatat bahwa tidak selalu kepentingan duniawi dan kenikmatannya bertentangan dengan nilai-nilai Ilahi, dan ketika itu tidak ada sal ahnya jika keduanya digabung. Sekali lagi, ancaman ayat di atas ditunjukikan pada situasi dimana diharuskan adanya pilihan menyangkut dua hal yang tidak dapat digabung (Quraish Shihab, 2011).

Ke-empat, Al-Qur'an Surat An-Nur (24) Ayat 37, yang artinya : “Laki-laki yang tidak dilalaikan oleh perniagaan dan tidak (pula) oleh jual beli dari mengingati Allah, dan (dari) mendirikan sembahyang, dan (dari) membayarkan zakat. mereka takut kepada suatu hari yang (di hari itu) hati dan penglihatan menjadi goncang". Tijarah dalam ayat ini diartikan sebagai "perniagaan". Mereka itu yang berkonsentrasi dalam ibadah sehingga jual beli dan perdagangan tidak melalaikan mereka dari mengingat Allah. Pujian yang diberikan kepada mereka disebabkan keimanan mereka ketika itu masih dinilai sahih dan ketika itupun ajaran Islam belum mereka kenal (Quraish Shihab, 2011).

Kelima, AI-Qur'an Surat Fathir (35) A yat 29, yang artinya : “Sesungguhnya orang-orang yang selalu membaca Kitab Allah dan mendirikan shalat dan menafkahkan sebahagian dari rezki yang kami anugerahkan kepada mereka dengan diam-diam dan terang-terangan, mereka itu mengharapkan perniagaan yang tidak akan merugi." Tijarah dalam ayat ini diartkan sebagai "perniagaan". Ada tiga hal kemungkinan bagi seorang pemilik harta untuk menggunakan hartanya, pertama, dibelanjakan, kedua, diinvestasikan, dan ketiga, ditumpuk. Ketiga hal ini, jika menimbulkan kerusakan akhlak, dilarang keras oleh al-Qur'an, seseorang boleh membelanjakan hartanya asal tidak mengakibatkan pemborosan atau membuang-buangnya. Seseorang tidak dibenarkan menggunakan hartanya untuk hal-hal yang tidak bermanfaat, apalagi yang sejak awal telah diharamkan, seperti berjudi, berzina, dan minum minuman keras, bahkan seseorang yang terbiasa memberi bantuan bukan pada tempatnya dapat dikenakan pembatasan kewenangan menggunakan hartanya (Shihab, 2011).

Ke-enam, Al-Qur'an Surat Ash-Shaf (61) Ayat 10, yang artinya : “Hai orang-orang yang beriman, sukakah kamu A ku tunjukkan suatu perniagaan yang dapat menyelamatkanmu dari azab yang pedih?". Tijarah dalam ayat ini diartikan sebagai "perniagaan". Perniagaan itu adalah perjuangan di jalan Allah yakni beriman kepada Allah dan Rasul-Nya dan berjihad, yakni bersungguhsungguh dari saat ke saat mencurahkan apa yang kamu miliki berupa tenaga, pikiran, waktu, dan dengan harta-harta dan jiwa-jiwa kamu masing-masing dijalan Allah (Quraish Shihab, 2011).

Ketujuh, AI-Qur'an Surat AI-Baqarah (2) A yat 16, yang artinya : “M ereka Itulah orang yang membeli kesesatan dengan petunjuk, $M$ aka tidaklah beruntung perniagaan mereka dan tidaklah mereka mendapat petunjuk." Tijarah dalam ayat ini diartikan sebagai "perniagaan". Penukaran diibaratkan dengan jual beli untuk mengisyaratkan bahwa apa yang dilakukannya itu terlaksana dengan kerelaan, sebagaimana layaknya semua jual beli. Selanjutnya, karena setiap jual beli pasti dimotivasi oleh perolehan keuntungan, disini ditegaskan bahwa perniagaan mereka tidak menghasilkan.

Kedelapan, AI-Qur'an Surat Al-Jumu'ah (62) Ayat 11, yang artinya : “D an apabila mereka melihat perniagaan atau permainan, mereka bubar untuk menuju kepadanya dan mer kka tinggalkan kamu sedang berdiri (berkhotbah). Katakanlah: "A pa yang di sisi Allah lebih baik daripada permainan dan 
perniagaan", dan Allah sebaik-baik pemberi rezki." Tijarah dalam ayat ini diartikan sebagai "perniagaan". Kaum Muslimin diperintahkan agar menghadiri ibadah shal at Jum'at, tetapi ada sekelompok orang yang Ialai (karena perniagaan) dan tidak memenuhi secara baik perintah tersebut. Ayat di atas mengecam mereka dan tidak lagi mengarahkan pembicaraan kepada mereka, untuk mengisyaratkan bahwa mereka tidak pantas mendapat kehormatan diajak berdial og dengan Allah (Quraish Shihab, 2011).

Dari delapan ayat AI-Qur'an yang menjelaskan tentang tijarah (perdagangan/ perniagaan) tersebut di atas, penulis dapat mengambil kesimpulan sebagai berikut : Tijarah yang tidak tunai harus ada pencatatan dan saksi. Tijarah harus berdasarkan kerelaan (saling ridho), dan harta tidak diperoleh dengan jalan batil. Tijarah harus tidak lebih dicintai dari pada cintanya kepada Allah, Rasul, dan Jihad. Tijarah harus tidak melalaikan shalat, zakat, takutnya hari kiamat. Tijarah harus tidak meninggal kan ibadah wajib, karena Allah-lah pemberi rezki.

Selanjutnya, untuk melengkapi dalil-dalil terkait dengan Tijarah (perdagangan / perniagaan) penulis mengambil beberapa Hadits, sebagai berikut :

\section{Dari A bu Sa'id Al-Khudri Ra, Nabi Saw bersabda:}

"Pedagang yang senantiasa jujur lagi amanah akan bersama para nabi, orang-orang yang selalu jujur dan orang-orang yang mati syahid." (HR Tirmidzi, Kitab Al-Buyu' Bab Ma Ja-a Fit Tijaroti no. 1130).

Dari Mu'adz bin Jabal Ra, ia berkata: Rasulullah Saw bersabda:

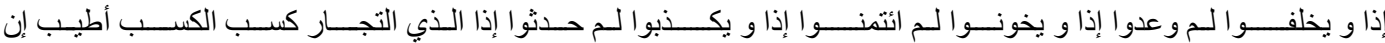

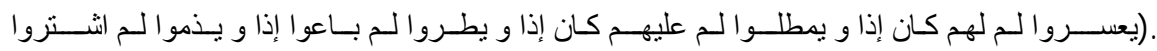

"Sesungguhnya sebaik-baik penghasilan ialah penghasilan para pedagang yang mana apabila berbicara tidak bohong, apabila diberi amanah tidak khianat, apabila berjanji tidak mengingkarinya, apabila membeli tidak mencela, apabila menjual tidak berlebihan (dalam menaikkan harga), apabila berhutang tidak menunda-nunda pelunasan dan apabila menagih hutang tidak memperberat orang yang sedang kesulitan." (HR Al-Baihaqi di dalam Syu'abul Iman, Bab Hifzhu AI-Lisan IV/ 221).

Nabi Saw bersabda:

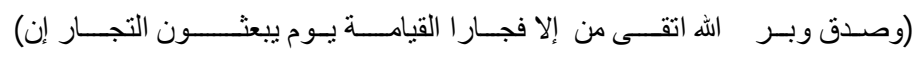

"Sesungguhnya para pedagang (pengusaha) akan dibangkitkan pada hari kiamat sebagai para penjahat kecuali pedagang yang bertakwa kepada Allah, berbuat baik dan jujur." (HR Tirmidzi, Kitab Al-Buyu' Bab Ma Ja-a Fi At-Tujjar no.1131).

Dari tiga hadits yang menjelaskan tentang tijarah (perdagangan / perniagaan) tersebut di atas, penulis dapat mengambil kesimpulan sebagai berikut : pertama, pedagang (pelaku tijarah) yang jujur bersama nabi, shiddiqin, dan syuhada. Kedua, pedagang (pelaku tijarah) yang tidak bohong, tidak khianat, tidak mengingkari janji, tidak mencela, tidak menaikkan harga berlebi han, tidak menunda-nunda pelunasan, dan tidak memberatkan yang sedang kesulitan, sebaik-baik penghasilan.

A kad Tijarah dalam Ekonomi Islam

Manusia sebagai makhluk sosial mendorong untuk saling berhubungan satu sama lainnya agar dapat memenuhi kebutuhannya, maka dibutuhkan aturan hukum yang mengatur hubungan 
tersebut. Sebab jika tidak ada hukum yang mengaturnya, akan terjadi kekacauan dalam kehidupan manusia. Kontruks (rancang-bangun) ekonomi Islam adal ah sebuah tatanan ekonomi yang dibangun atas dasar ajaran tauhid dan prinsip-prinsip moral Islam (seperti moral keadilan), dibatasi oleh syariah Islam (misalnya aturan halal dan haram) dan fikih (hukum Islam yang bersifat furu'iyah) (Mas'adi, 2002).

Salah satu bentuk aturan hukum yang dibutuhkan dalam masyarakat adalah mengenai transaksi ekonomi, yang berfungsi untuk menjaga stabilitas kehidupan sehingga masyarakat dalam melakukan transaksi tetap dalam hal-hal yang sesuai dengan aturan hukum yang dimaksud.

Sementara pengertian akad, menurut para ahli hukum Islam diartikan sebagai hubungan antara ijab dan kabul sesuai kehendak syariat yang menetapkan adanya pengaruh (akibat) hukum pada obyek perikatan. Sedangkan Dewan Syariah Nasional dalam fatwanya No. 45/ DSN-MUI/II/ 2005 mengartikan akad sebagai transaksi atau perjanjian syar'i yang menimbulkan hak dan kewajiban (Fatwa Dewan Syariah Nasional No 45/D SN-M UI/II/2005 tentangLine F acility).

Sebagaimana penulis sebutkan di bab pendahuluan bahwa dalam Islam mengenal dua macam akad yaitu : Akad tijarah dan akad tabarru'. Akad tabarru' bertujuan untuk tolong menol ong dalam rangka berbuat kebaikan, dan akad tijarah bertujuan untuk mencari keuntungan karena itu bersifat komersial. Hal ini juga disebutkan (Mustofa et al., 2014) bahwa dalam transaksi ekonomi secara garis besar akad dibagi menjadi dua kategori, yaitu akad komersial dan akad non-komersial. Akad komersial (akad tijarah) adalah akad atau perjanjian yang bertujuan untuk mencari keuntungan finansial, sedangkan akad non-komersial (akad tabarru') adalah akad atau perjanjian yang tidak menghasilkan keuntungan finansial yang bertujuan untuk mewujudkan kebaikan sosial seperti prinsip tolong-menolong (Mustofa et al., 2014). Karim, (2007) memberikan penjelasan tentang akad tijarah adalah segala macam perjanjian yang menyangkut for profit transaction. Akad-akad ini dilakukan untuk mencari keuntungan, karena bersifat komersial.

Selanjutnya dalam buku yang sama (Adiwarman A. Karim, 2007) membagi akad tijarah atau transaksi komersial menjadi dua, yaitu :

N atural Certainty Contracs (N CC).

Yang dimaksud dengan natural certainty contracs adalah akad dalam bisnis yang memberikan kepastian pembayaran, baik dari segi jumlah (amount) maupun waktu (timing)-nya. Cash flow-nya bisa diprediksi dengan relatif pasti, karena sudah disepakati oleh kedua belah pihak yang telah bertransaksi di awal akad (Karim, 2007). Yang termasuk dalam kategori NCC yaitu (Adam, 2017):

1. Prinsip Jual-beli. AI-M urabahah, adalah jual-beli dengan dasar adanya informasi dari pihak pennjual terkait dengan harga pokok pembelian dan tingkat keuntungan yang diinginkan. Bai' salam, adalah transaksi jual-beli yang pembayarannya dilakukan dimuka secara tunai sementara barangnya diserahkan di kemudian hari/ ditangguhkan. Bai' istisna, adalah akad antara dua orang di mana salah seorang mustashni' (pemesan) meminta dibuatkan sesuatu dengan karakteristik tertentu kepada pembuatnya (shani'). Dijelaskan (Adam, 2017) bahwa ulama Hanafi menyatakan bahwa akad istishna' termasuk dalam jual-beli.

2. Prinsip Sewa-menyewa. Ijarah, adalah akad terhadap manfaat dengan waktu tertentu disertai imbalan atau pengganti tertentu pula. Terkait dengan akad Ijarah ini dalam fatwa DSN-MUI dijelaskan bahwa "perjanjian sewa-menyewa yang disertai dengan opsi 
perpindahan hak milik atas benda yang disewa kepada penyewa setelah selesai masa sewa" disebut sebagai A I-Ijarah A I-M umtahiyah Bi A I-Tamlik.

N atural U ncertainty Contracs (N U C).

Yang dimaksud dengan natural uncertanty contracs adalah kontrak atau akad dalam bisnis yang tidak memberikan kepastian pendapatan (return), atau dengan prinsip bagi hasil. Tingkat return bisa positif, negatif, atau nol. Yang termasuk kategori NUC yaitu:

1. Al-M udharabah, adalah penyerahan harta (modal) terhadap seseorang untuk diperniagakan (digolangkan), sedangkan keuntungannya dibagikan diantara mereka (pemodal dan yang diberi modal) (Nurhasanah, 2015). Dalam hasanah fikih muamalah mudharabah tidak bisa dilepaskan dari konsep syirkah karena mudharabah bagian dari syirkah. Syirkah merupakan perkongsian atau bentuk usaha kerjasama usaha tertentu guna mendapatkan keuntungan (berorientasi pada profit). (Maulana Hasanudin dan Jaih Mubarok dalam Adam, 2017). Adapun dalam syirkah al-mudharabah, keuntungan dibagi antara pemilik modal (shahib al-mal) dengan pelaku usaha/ pebisnis/ mudharib berdasarkan nisbah yang disepakati, kerugian dibebankan hanya kepada shahib al-mal, kecuali kerugian tersebut terjadi karena kelalaian mudharib (Mubarok, 2003)

2. A I-M uzaraah, adalah akad kerjasama atas pertanian antara pemilik lahan dan penggarap, dimana pemilik lahan pertanian memberikan lahan pertanian kepada penggarap untuk ditanami dan dipelihara dengan imbalan tertentu (prosentasi) dari hasil panen. (Adam, 2017)

3. A I-M usaqah, adalah akad kerjasama terhadap pengelolaan pohon atau kebun dengan keuntungan buah yang dihasilkannya berdasarkan persentase bagi hasil yang telah ditentukan menurut kesepakatan kedua belah pihak antara pemilik pohon dengan petani penggarap. (Adam, 2017)

A kad Tijarah dalam Praktek Lembaga Keuangan M ikro Syariah BM T.

Baitul M al wat-Tamwil sebagai Sistem Ekonomi Islam

Dalam buku pembiayaan bank syariah Wangsawidjaja (2012) menjelaskan bahwa : “Fungsi baitul mal sebagai lembaga yang mengumpulkan harta dan menyalurkan untuk kemaslahatan rakyat tersebut, menurut hemat Penulis identik dengan fungsi bank sebagai lembaga intermediary, yaitu sebagai penyimpan dan penyalur dana masyarakat sebagaimana telah diuraikan di atas. Karena itu, berdasarkan sejarahnya, dapat dikatakan bahwa baitul mal merupakan cikal bakal dari lahirnya perbankan syariah.

Selanjutnya Wangsawidjaja (2012) mengutip pendapat Harun Nasution dalam Ensiklopedia Islam Indonesia bahwa Terminologi baitul mal wa al-tamwil berasal dari 2 (dua) kata, yaitu baitu al-mal dan baitul tamwil. Istilah al-mal dari kata bait berarti bangunan atau rumah, sedangkan al-mal artinya harta benda atau kekayaan. Jadi baitu al-mal berarti rumah harta benda atau kekayaan. Namun, baitul mal juga diartikan sebagai perbendaharaan (umum atau negara). Sedangkan baitul mal dilihat dari istilah fikih adalah suatu lembaga yang bertugas mengurusi kekayaan negara terutama keuangan, baik berkenaan dengan pemasukan dan pengel olaan, maupun yang terkait dengan pengeluaran. Sedangkan baitul tamwil berarti rumah penyimpanan harta milik pribadi yang dikelola oleh suatu lembaga.

Salah satu kondisi sosial ekonomi adalah semakin melebarnya disparitas antara pengusaha besar disatu sisi dengan pengusaha kecil dan mikro di sisi lainnya. Pengusaha besar mendapat banyak kemudahan dari lembaga keuangan, dengan alasan mendukung industrialisasi dan memacu pertumbuhan ekonomi. Sedangakn pengusaha kecil kurang mendapat fasilitas serta nyaris tidak terlayani oleh lembaga keuangan formal seperti bank. Pihak yang bersedia melayani adalah yang mengambil rente besar, seperti lintah darat, bank plecit, dan sejenisnya. BMT berupaya membiayai para pengusaha mikro sambil bersaing dengan para lintah darat. Pada saat bersamaan, BMT melakukannya dengan upaya menerapkan nilai-nilai Islami, antara lain dengan 
sistem bagi hasil, yang jika dilihat dari sisi pengusaha mikro terasa memiliki margin lebih rendah atau lebih murah.

Perkembangan kemampuan BMT dalam memberikan pembiayaan selanjutnya dapat dikatakan sangat spektakuler. Selama bertahun-tahun hingga kini, rasio financing to deposit rasio (FD R) BMT pada umumnya berada di kisaran angka 100 persen. Artinya dana yang dihimpun dari anggota dan nasabah dapat disalurkan sepenuhnya, bahkan sering tidak mencukupi (Haluan BMT, 2012).

Dalam Buku Haluan BMT 2020 yang diterbitkan oleh Perhimpunan BMT Indonesia Maret 2012 disebutkan bahwa Sejarah perjuangan BMT di bagian lain adalah terkait erat dengan semangat kaum muslimin di seluruh dunia pada era 70-an untuk meningkatkan aktualisasi nilainilai Islam dalam kehidupan ekonomi modern. Keyakinan akan Islam sebagai rahmatan Iil'alamin, khususnya dalam soal ajaran sosial ekonomi, membuat gairah dalam wacana ilmiah maupun yang bersifat empiris dan operasional semarak pula di Indonesia. Penerbitan buku, kajian ilmiah, sampai dengan uji coba beberapa instrumen banyak dilakukan. Di beberapa Negara, era itu sudah memulai menyelenggarakan program studi khusus ekonomi dan keuangan Islam. Upaya meningkatkan profesionalisme membawa BMT kepada berbagai inovasi kegiatan usaha dan produk usaha. Sesuai dengan kondisi "lapangan" masing-masing, BMT berkreasi menciptakan bentuk, nama dan jenis kegiatan penghimpunan dan penyaluran dana. BMT sering menggunakan slogan atau semboyan yang dianggap bisa menjadi "branch" atau ciri khas mereka, yang biasanya juga diilhami oleh kondisi masyarakat yang dilayani.

Faktor regulasi ada pula yang mendukung perkembangan BMT dalam beberapa tahun terakhir. Sebelumnya, kebanyakan BMT masih merasa gamang akan status legalnya, karena departemen koperasi hanya mencantumkan dalam peraturan menteri bahwa koperasi dalam operasionalnya dapat menggunakan pola syariah. Akan tetapi semenjak ditetapkannya KEPMEN Nomor 91/ KEP/ M.KUKM/ IX/ 2004 tentang Petunjuk Pelaksanaan Kegiatan Usaha Koperasi Jasa Keuangan Syariah, dapat dirasakan bahwa gerakan BMT telah mendapat kepastian hukum. Bahkan, dalam Petunjuk Pelaksanaan (juklak) dan Petunjuk Teknis (juknis) yang dikeluarkan Pemerintah, telah terdapat Standar Operasional Prosedur (SOP) maupun Standar Operasional Manajemen (SOM) yang relatif memenuhi harapan BMT dari sisi syariah, sehingga kedepan gerakan BMT dapat segera mentransformasi dirinya kedalam upaya profesionalisme lembaga keuangan syariah dengan menerapkan Ketundukan Syariah (Syariah Comliance) dan Good Corporate Governance (GCG). Permen dimaksud adalah PERMEN Nomor 35.2/ PER/ M.KUKM/ X/ 2007 tentang Pedoman Standar Operasional Manajemen Koperasi Jasa Keuangan Syariah dan Unit Usaha Jasa Keuangan Syariah (Haluan BMT, 2020).

Sebagian besar BMT memiliki dua latar belakang pendirian dan kegiatan yang hampir sama kuat, yakni sebagai lembaga keuangan mikro dan sebagai lembaga keuangan syariah. Perkembangan pesat dimulai sejak tahun 1995, dan memperoleh "momentum" tambahan akibat krisis ekonomi 1997/ 1998. Sekarang bisa dikatakan bahwa masyarakat luas telah cukup mengetahui tentang keberadaan BMT. A da sekitar 3.900 BMT yang beroperasi di Indonesia pada akhir tahun 2010 (Haluan BMT, 2020).

Dalam acara Silaturahmi Nasional Perhimpunan BMT Indonesia yang diselenggarakan di Jakarta pada tanggal 6-8 N opember 2018 dengan Tema Peran Gerakan BMT dalam Memperkuat Ekonomi Negeri, Menteri KUKM menyatakan bahwa : "Saat ini, Indonesia menjadi negara dengan jumlah industri keuangan syariah terbanyak di dunia. Antara lain, terdapat 5000 institusi lembaga keuangan syariah, meliputi 34 perbankan syariah, 58 operator Takaful/ Asuransi Syariah, tujuh perusahaan modal ventura syariah, 163 BPR Syariah, 4500 BMT, dan satu institusi pegadaian syariah.

Terkait dengan regulasi sebagaimana disebutkan di atas, pada saat ini lembaga keuangan mikro syariah yang berbadan hukum koperasi masih berjuang untuk bisa dimasukkan dalam rancangan pengganti undang-undang koperasi yang ada. Namun demikian dengan Keputusan Menteri KUKM yang ada sudah dapat dijadikan sebagai payung atau landasan operasional BMT. Keputusan Menteri KUKM sendiri telah beberapa kali mengalami perubahan setelah dikeluarkan Kepmen KUKM Nomor 91/ KEP/ M.KUKM/ IX/ 2004, dilakukan perubahan dengan Peraturan 
Menteri KUKM Nomor 16/Per/M.KUKM/IX/2015, dilakukan perubahan Nomor 11/ PER/ M.KUKM/ XII/ 2017.

Praktek A kad Tijarah di Lembaga Keuangan M ikro Syariah BM T.

Akad atau perjanjian pembiayaan memiliki berbagai macam istilah, antara lain Perjanjian Pembiayaan, Persetujuan Membuka Pembiayaan, dan sebagainya. Disamping mengatur hak dan kewajiban bank serta nasabah, perjanjian atau persetujuan antara bank dengan nasabah penerima fasilitas pembiayaan (debitur) juga berfungsi sebagai perikatan pokok dari perjanjian pengikatan jaminan (accessoir) (wangsawidjaya, 2012).

Dal am menjalankan kegiatan usaha, BMT yang merupakan subsistem dari sistem ekonomi syariah wajib memenuhi asas-asas yang sesuai dengan prinsip syariah. Terdapat beberapa nilai dasar/ asas yang merupakan pilar utama dari akad-akad atau perjanjian berdasarkan prinsip syariah. (Fathurrahman Djamil dalam Wangsawidjaja, 2012) A sas-asas perjanjian syariah adalah kebebasan (al-hurriyah), persamaan atau kesetaraan (al-musawah), keadilan (al-adalah), kerelaan (al-ridha), kejujuran dan kebenaran (ash-shidiq), dan asas tertulis (al-kitabah).

Selanjutnya dalam praktek atau implementasi akad tijarah sebagaimana dijelaskan dalam uraian di atas di lembaga keuangan mikro syariah yang dalam hal ini mengambil satu dari sejumlah BMT yang ada Indonesia. BMT TUMANG adalah Koperasi Simpan Pinjam dan Pembiayaan Syariah (KSPPS) yang didirikan pada tahun 1998 dengan Badan Hukum No 242/ BH/ KDK.11.25/ IV/ 1999 (jangkauan wilayah Kabupaten Boyolali), PAD No 02/ PAD/XIV/ I/ 2011 (jangkauan wilayah Propinsi Jawa Tengah), PAD No 166/ LapPAD/ VIII/ 2016 (jangkauan wilayah Nasional), dan merupakan 100 Koperasi Besar Indonesia (Indonesia's 100 Largest Cooperatives) tahun 2017. BMT TUMANG telah dilengkapi dengan standar operasional manajemen (SOM) dan standar operasional prosedur (SOP) yang juga telah diberikan panduan dari Kementerian KUKM. Kerjasama perdagangan atau perniagaan atau dalam hal ini melalui pembiayaan dengan pihak anggota telah diterbitkan SOM70 tentang Penyaluran Dana, yang secara umum diberikan penjelasan, tentang : manfaat sosial; keuntungan; biaya administrasi; strategi penetapan nisbah bagi hasil, marjin, dan ujroh; persyaratan umum pembiayaan; usulan pembiayaan; prinsip pemberian persetujuan pembiayaan; proses realisasi pembiayaan; dana tabarru'; dana ta'awun; agunan; notariil; pengendalian risiko; organisasi dan manajemen; plafon pembiayaan; kelebihan dana; pembiayaan bermasalah; dan prinsip akad pembiayaan dan pinjaman.

Berikut ini secara khusus telah diterbitkan pula SOM dan SOP terkait dengan akad tijarah, yaitu:

1. A kad A I-M urabahah. SOM 71 tentang Penyaluran Dana: A kad M urabahah menetapkan sebagai berikut:

a) BMT dan Anggota harus melakukan akad murabahah yang bebas riba.

b) Barang yang diperjual-belikan tidak diharamkan oleh syariah Islam.

c) BMT membiayai sebagian atau seluruh harga pembelian barang yang telah disepakati kualifikasinya.

d) BMT membeli barang yang diperlukan Anggota atas nama BMT sendiri, dan pembelian ini harus sah dan bebas riba.

e) BMT harus menyampaikan semua hal yang berkaitan dengan pembelian, misalnya jika pembelian dilakukan secara hutang.

f) BMT kemudian menjual barang tersebut kepada Anggota dengan harga jual senilai harga beli ditambah keuntungannya. Dalam kaitan ini BMT harus memberitahu secara jujur harga pokok barang kepada Anggota berikut biaya yang diperlukan.

g) Anggota membayar harga barang yang telah disepakati dan pada jangka waktu tertentu yang tel ah disepakati.

h) Untuk mencegah terjadinya penyalahgunaan atau kerusakan akad, pihak BMT dapat mengadakan perjanjian khusus dengan Anggota. 
i) Jika BMT hendak mewakilkan kepada Anggota untuk membeli barang dari pihak ketiga, akad jual beli murabahah harus dilakukan setelah barang secara prinsip menjadi milik BMT.

2. A kad AI-Salam. Tidak mengeluarkan pembiayaan pada jenis ini.

3. Akad Al-Istishna'. Tidak mengeluarkan pembiayaan pada jenis ini.

4. A kad A I-Ijarah. SOM 72 tentang Penyal uran Dana: Akad Ijarah menetapkan sbb :

a) Obyek ijarah adalah manfaat dari penggunaan barang/ jasa.

b) Manfaat barang/ jasa harus bisa dinilai dan dapat dilaksanakan dalam kontrak.

c) Pemenuhan manfaat harus yang bersifat dibolehkan.

d) Kesanggupan memenuhi manfaat harus nyata dan sesuai dengan syariah.

e) Manfaat harus dikenali secara spesifik sedemikian rupa untuk menghilangkan ketidaktahuan (jahalah) yang akan mengakibatkan sengketa.

f) Spesifikasi manfaat harus dinyatakan dengan jelas, termasuk jangka waktunya. Bisa juga dikenali dengan spesifikasi atau identifikasi fisik.

g) Sewa adalah sesuatu yang dijanjikan dan dibayar Anggota kepada BMT sebagai pembayaran manfaat. Sesuatu yang dapat dijadikan harga dalam jual beli dapat pula dijadikan sewa dalam ijarah.

h) Pembayaran sewa boleh berbentuk jasa (manfaat lain) dari jenis yang sama dengan obyek kontrak.

i) Kelenturan (flexibility) dalam menentukan sewa dapat diwujudkan dalam ukuran waktu, tempat dan jarak.

j) Kewajiban BMT sebagai pemberi sewa : Menyediakan barang yang disewakan; Menanggung biaya pemeliharaan barang; Menjamin bila terdapat cacat pada barang yang disewakan.

k) Kewajiban Anggota sebagai penyewa : Membayar sewa dan bertanggungjawab untuk menjaga keutuhan barang yang disewa serta menggunakannya sesuai kontrak; Menanggung biaya pemeliharaan barang yang sifatnya ringan (tidak materiil); Jika barang yang disewa rusak, bukan karena pelanggaran dari penggunaan yang dibolehkan, juga bukan karena kelalaian pihak penyewa dalam menjaganya, ia tidak bertanggungjawab atas kerusakan tersebut.

5. A kad A I-Ijarah M umtahiyah Bi A I-Tamlik. Tidak mengeluarkan pembiayaan pada jenis ini.

6. A kad A I-M udharabah. SOM 73 tentang Penyaluran Dana: A kad M udharabah menetapkan sbb :

a) Pembiayaan disalurkan oleh BMT kepada Anggota untuk suatu usaha yang produktif.

b) BMT sebagai pemilik dana membiayai $100 \%$ kebutuhan usaha, sedangkan Anggota bertindak sebagai pengelola usaha.

c) Jangka waktu usaha, tata cara pengembalian dana, dan pembagian keuntungan ditentukan berdasarkan kesepakatan BMT dengan Anggota.

d) Anggota boleh melakukan berbagai macam usaha yang telah disepakati bersama dan sesuai dengan syariah.

e) BMT tidak ikut serta dalam manajemen perusahaan atau proyek tetapi mempunyai hak untuk melakukan pembinaan dan pengawasan.

f) Jumlah dana pembiayaan harus dinyatakan dengan jelas dalam bentuk tunai dan bukan piutang.

g) Biaya operasional dibebankan kepada Anggota.

h) Pernyataan ijab dan qabul harus dinyatakan oleh para pihak untuk menunjukkan kehendak mereka dalam mengadakan kontrak (akad), dengan memperhatikan hal-hal berikut: Penawaran dan penerimaan harus secara tegas menunjukkan tujuan kontrak (akad); Penerimaan dari penawaran dilakukan pada saat kontrak. A kad dituangkan secara tertulis, melalui surat-menyurat, atau dengan menggunakan cara-cara komunikasi modern.

i) Keuntungan mudharabah adalah jumlah yang didapat sebagai kelebihan dari modal. Syarat keuntungan: Harus diperuntukkan bagi kedua pihak dan tidak boleh disyaratkan hanya untuk satu pihak; Bagian keuntungan proporsional bagi setiap pihak harus diketahui dan 
dinyatakan pada waktu kontrak disepakati dan harus dalam bentuk prosentasi (nisbah) dari keuntungan sesuai kesepakatan. Perubahan nisbah harus berdasarkan kesepakatan.

j) BMT menanggung semua kerugian akibat dari mudharabah, dan Anggota tidak boleh menanggung kerugian apapun kecuali diakibatkan dari kesalahan disengaja, kelalaian, atau pelanggaran kesepakatan.

7. Akad AI-M usyarakah. SOM 74 tentang Penyaluran Dana: Akad M usyarakah. Dalam kerjasama ini yaitu pihak anggota menyertakan dana atau modal kerja namun karena BMT "tidak mengatur aset musyarakah" dan "tidak berpartisipasi dalam pekerjaan" sebagaimana diatur dalam akad musyarakah, maka BMT menggunakan akad mudharabah musytarakah.

8. A kad A I-M uzaraah. Tidak mengeluarkan pembiayaan pada jenis ini.

9. Akad A I-M usaqah. Tidak mengeluarkan pembiayaan pada jenis ini.

\section{Kesimpulan}

Kesimpulan

Transaksi ekonomi tidak lepas dari kebutuhan manusia dan Islam telah mengatur dengan jelas dan tegas khususnya yang berhubungan dengan perniagaan/ perdagangan atau tijarah, dan oleh karenanya wajib untuk diikuti karena bersinggungan dengan hukum-hukum agama, antara lain: ada pencatatan dan saksi; berdasarkan kerelaan (saling ridho), dan harta tidak diperoleh dengan jalan batil; tidak lebih dicintai dari pada cintanya kepada Allah, Rasul, dan Jihad; tidak melalaikan shalat, zakat, takutnya hari kiamat; jujur; tidak bohong; tidak khianat; tidak mengingkari janji; tidak mencela; tidak menaikkan harga berlebihan; tidak menunda-nunda pelunasan; tidak memberatkan yang sedang kesulitan.

Dalam hal tijarah ada beberapa jenis akad (kesepakatan) yang disesuaikan dengan keperluannya yang masing-masing telah ditetapkan bagaimana harus dilakukan, yaitu : prinsip jual-beli (al-murabahah, al-salam, al-istishna'); prinsip bagi-hasil (al-mudharabah, al-musyarakah/almudharabah musytarakah, al-muzaraah, al-musaqah). Lembaga keuangan mikro syariah yang dalam hal ini BMT TUMANG telah menjalankan prinsip syariah dalam praktek khususnya untuk akad tijarah dengan adanya dokumen-dokumen berupa SOM dan SOP serta kontrak (kesepakatan) pembiayaan baik dalam prinsip jual-beli maupun prinsip bagi hasil.

Implikasi

Sepanjang yang diketahui penulis, sebagian besar BMT telah menjalankan prinsip syariah untuk akad tijarah, namun sepertinya belum semua dilengkapi dengan SOM dan SOP sebagai penjabaran dari fatwa DSN-MUI yang ada. Lebih lagi lembaga keuangan mikro syariah pada umumnya. Oleh karena itu penulis memberikan saran agar dilengkapi SOM dan SOP karena dalil-dalil Al-Qur'an dan Al-Hadits harus dijelaskan lagi secara operasional untuk memberi kemudahan bagi anggota dan pihak manapun memahaminya. Disamping itu secara lembaga keuangan syariah dalam operasionalnya harus konsisten dengan prinsip syariah yang benar atau sesuai dengan yang dicontohkan $\mathrm{N}$ abi shallallahu 'alaihi wa sallam.

Dalam upaya untuk mengedukasi masyarakat (umat) agar memahami prinsip syariah dalam bermuamalah (transaksi ekonomi/ tijarah) hendaknya para juru dakwah lebih banyak juga menyampaikan dakwahnya dalam konteks muamalah maliyah. Sehingga semakin banyak pula umat bertransformasi ke prinsip syariah yang jauh dari riba, berkah, dan pastinya akan menjdi bagian dari pengamalan agama.

Keterbasan

Penelitian dilakukan hanya pada salah satu Lembaga keuangan mikro syariah sehingga tidak 
menggambarkan praktik yang terjadi di lembaga lainnya. Penelitian mendatang perlu melakukan perbandingan antar lembaga untuk memperoleh gambaran yang lebih luas dan hasilnya lebih dapat digeneral isasi.

\section{D aftar Pustaka}

Adam, P. (2017). Fikih M uamalah M aliyah, Bandung: Refika Aditama.

Athoillah, A. dan Q-Anees, B. (2013). Filsafat Ekonomi Islam. Retrieved from http://digilib.uinsgd.ac.id/id/eprint/1749

AI-Qur'an Terjemah Tajwid, Kementerian Agama RI, 2010, Jakarta: Rumah Zakat.

Dewan Syariah Nasional MUI, Fatwa Dewan Syariah N asional No 45/D SN -M UI/II/2005 tentangLine Facility (At-T ashilat A s-Saqfiyah), Jakarta 2005.

Dewan Syariah Nasional MUI, Fatwa D ewan Syariah N asional N 0. 27/D SN -M U I/III/2002 tentang A IIjarah A I-M umthiyah Bi A I-Tamlik, Jakarta, 2002.

Dewan Syariah Nasional MUI, Fatwa D ewan Syariah N asional N omor 08/D SN -M U I/IV /2000 tentang Pembiayaan M usyarakah, Jakarta, 2000.

Dewan Syariah Nasional MUI, Fatwa D ewan Syariah N asional N omor 50/D SN -M UI/III/2006 tentang A kad M udharabah M usytarakah, Jakarta, 2006.

Ghufron A. Mas'adi, Fikih Muamalah Kontekstual, Jakarta: PT RajaGrafindo Persada, 2002.

Karim, A. A. (2007). Bank Islam: A nalisis fiqih dan keuangan edisi ketiga. Jakarta PT. Raja G rafindo Persada.

Hadits Riwayat Ibnu Majah dari Suhaib Al-Rumi Ra.

Hendryadi, H., Tricahyadinata, I., \& Zannati, R. (2019). M etode Penelitian: Pedoman Penelitian Bisnis dan A kademik. Jakarta: LPMP Imperium.

Mustofa, A. (2014). Reorientasi Ekonomi Syari'ah. Yogyakarta: UII Press Yogyakarta (A nggota IKAPI).

Perhimpunan BMT Indonesia. (2020). Haluan BMT 2020, Jakarta.

https:/ / abufawaz.wordpress.com/ 2012/ 04/ 10/ hadits-hadits-shohih-tentang-keutamaanperniagaan-dan-pengusaha-muslim/, di akses pada tanggal 05 N opember 2019.

https:/ / www.wartaekonomi.co.id/ read202325/ menkop-dan-ukm-minta-dana-bergulir-untukbmt-segera-direalisasikan.html, diakses pada tanggal 8 Oktober 2019.

Mubarok, J. (2003). H ukum E konomi Syariah: A kad M udharabah, Bandung: Fokusmedia

KSPPS BMT TUMANG, Standar Operasional Manajemen: SOM70 Penyaluran Dana, Rev-3, tanggal 15-01-2019.

Nurhasanah, N. (2015). M udharabah, Bandung: Refika Aditama.

Peraturan Menteri Koperasi dan Usaha Kecil dan Menengah Republik Indonesia Nomor : 11/ PER/ M.KUKM/ XII/ 2017 tentang Pelaksanaan Kegiatan Usaha Simpan Pinjam dan Pembiayaan Syariah oleh Koperasi

Shihab, Q. (2011). M enabur Pesan Ilahi, A I-Qur'an dan Dinamika Kehidupan M asyarakat, Jakarta: Lentera Hati

Wangsawidjaja, A . (2012). Pembiayaan Bank Syariah, Jakarta: PT Gramedia Pustaka Utama

\section{About Authors}

Nandang Ihwanudin, Handri, Deden $\mathbf{G}$ andana Madjakusumah, M M unir Asrori. Program Studi Magister Manajemen Ekonomi Syariah, Universitas Islam Bandung. Corresponding author: $\mathrm{N}$ andang I hwanudin

email: nandangihwanudin_mes@unisba.ac.id 
SERAMBI: Jurnal Ekonomi Manajemen dan Bisnis Islam Published by LPMP Imperium

Accepted author version posted online: 30 April 2020

(c) (i)

(C) 2020 The Author(s). This open access article is distributed under a Creative Commons Attribution (CC-BY) 4.0 license 